Gonzalo Rojas. Contra la muerte. Segunda edición. Santiago de Chile: Editorial Universitaria, 1993.

A casi veinte años de la aparición del que fuera el segundo libro de Gonzalo Rojas, bajo el rótulo de la misma Editorial Universitaria, escribo estas líneas sobre una serie de poemas que antes conocía dispersamente. Incluidos en una antología editada por el Fondo de Cultura Económica en 1991, sólo ahora puedo leerlo tal como fuera concebido en los años sesenta.

De 1964 a 1993 la "situación de lectura" de la obra rojiana es visiblemente otra. Calificado de libro "fundacional" por muchos lectores y poetas de la década de los sesenta, Contra la muerte significó que su autor adquiriera algo así como un lugar seguro en el ámbito de la poesía chilena, después de haberse consagrado para unos pocos con su primer libro, La miseria del hombre (1948), inhallable incluso en los sesenta.

Para nosotros, lectores veinteañeros de Rojas, su obra se convierte en texto vivo, a partir de Del relámpago (FCE, 1981; segunda edición, 1984). Coincide la primera fecha con el retorno del poeta al país luego de su exilio. Bajo el brazo traía Oscuro (Caracas, 1977) y Transtierro (Madrid, 1979), pero al no ser distribuidos en Chile, la edición de 1981, que reunía gran parte de su obra desde 1948 en adelante, fue nuestra única fuente de lectura. El ejercicio circular encontraba pleno desarrollo, considerado éste como vuelta a lo mismo "en la simultaneidad del oleaje". No es exageración considerar a Del relámpago como la biografía de un poeta moderno de Hispanoamérica. Sin ser una "obra completa", es un libro que cartografía un vasto mapa poético, como ha dicho Julio Ortega.

Contra la muerte viene a ser entonces un remontar en las olas del tiempo para suscribirse a esa figura proteica que es la obra rojiana. Nuestra lectura del libro toma también los visos de un re-conocimiento, pero no comparándolo con la impresión de la primera entrega - no conocida - sino que restituyendo buena parte de la lectura del volumen de 1981. Pongo algunos ejemplos: la primera estrofa del bello y extenso poema "El amor" (Del relámpago, 109) aparece en Contra la muerte con el título de "Valparaíso". Otro: el fundamental poema "Crecimiento de Rodrigo Tomás" - excepcional muestra de la veta genealógica por la que se extiende parte de esta obra- que apareció en La miseria del hombre, pasa a Contra la muerte complementándose con "Oráculo" (que lo sigue en la página inmediatamente posterior). En 1981, dando muestras de una dialéctica morosa y ciudada, "Crecimiento de Rodrigo Tomás" posee dos "movimientos": ambos poemas ahora son uno y el mismo. Una dedicatoria ("A Alonso, hijo de Rodrigo, hijo de Gonzalo") más las fechas de composición de ambos movimientos" (1946 y 1964) cierran el ciclo de lectura. Pero en la página siguiente de Del relámpago tenemos el poema "El recién nacido", dedicado "A mi Gonzalo hijo / con sus ojos abiertos / desde antes". El ciclo que creíamos cerrado se reabre con el segundo hijo del poeta y nos hace mirar hacia adelante y hacia atrás: ¿cómo no relacionar estos dos poemas con otros como "Carbón", "Celia", "Cable sin él", etc., donde la progenie se nos presenta en un ejercicio de encantamiento?

Por último, el poema "Al fuego eterno" se llamaba en el libro de 1964 "Los compañeros", pero no sólo hay cambio de título sino que muy significativas variaciones en los versos: en la segunda línea, "Arenas" (Braulio) cambia en el volumen de 1981 a "Alguno" y, gesto muy decidor, en 1964, antes de la pregunta que finaliza el texto se nos 
dice: "Ahora / Lihn / tiene la palabra", en clara referencia a la buena impresión causada el año anterior por ese autor con su tercer libro, La pieza oscura. Este poema ha ido variando y agregando nombres ya que la poesía es "el fuego eterno"; el reconocimiento a "los compañeros" es la actitud de quien dice: "No soy David, ni San Juan de la Cruz ni Baudelaire .... Apenas uno más en el coro invisible".

Encanta y conmueve la fidelidad rojiana, hija de su estirpe romántica, al leer Contra la muerte, ejercicio de reedición que no cabe más que celebrar como al poeta le gustaría: juiciosa, críticamente.

\section{Marcelo Pellegrini}

Fernando Alegría. La rebelión de los placeres. Santiago de Chile: Editorial Andrés Bello, 1990.

Fernando Alegría acaba de publicar su última novela, La rebelión de los placeres (Editorial Andrés Bello), que abre un espacio ancho, una ventana luminosa por donde entran nuevos vientos a la casa de la novela chilena.

Esta casa, y sus derivados simbólicos, ha estado desde Casa grande de Orrego Luco marcada, o mejor dicho, carcomida por el derrumbe social de sus moradores, por pulsiones oscuras, deseos de lo de "otro", por perversiones que conducen a la locura o la muerte. Se trata, casi siempre, de espacios clausurados, oscuros, degradados que han perdido su función inicial; muchas veces se han transformado en recintos demoníacos donde parlotea "el obsceno pájaro de la noche" o se ejecuta aquelarres grotescos y ritmos inhumanos.

La novela chilena, en este sentido, padece de asfixia, aunque en otro nivel opuesto este ejercicio de contener la respiración la ha llevado a explorar profundas imágenes subterráneas de la conciencia chilena o aun "sudaca", como en el caso de Eltit.

Pero, en el hecho nos ha entregado una visión "imbunchada" de la existencia humana —ella habita caserones, prostíbulos, hoyos, ciudades cerradas, madrigueras, tal vez todas imágenes de un espacio uterino, pero despojado de rasgos protectores, lleno, por el contrario, de violencia, degradación y deseos incumplidos.

La novela chilena actual (de 1980 adelante), en términos generales, trabaja con el deshecho, un collage de residuos humanos, que como todo desperdicio frecuente lo excremental (en el sentido en que lo entienden Paz y Norman Brown) con excepciones: sin duda, Isabel Allende, en primer término, algunos recreadores de García Márquez con Walter Garib a la cabeza y un narrador que reemplaza la asfixia, la mutilación y el deshecho por la parodia y la ironía: Andrés Gallardo.

En este contexto Fernando Alegría llega a echar la casa por la ventana. Sacude los muebles, limpia el polvo y se pone a narrar con placer una historia llena de guiños, de embustes sabrosos, descarados, espiando siempre la reacción del escucha, del receptor, como lo hacían los viejos narradores populares: "El velero de tres palos había salido de Valparaíso el 28 de diciembre de 1848 con 148 pasajeros, 4 vacas, 8 chanchos, 12 ovejas, 3 perros, 15 gallinas y 10 tripulantes, incluyendo al capitán y al piloto". 